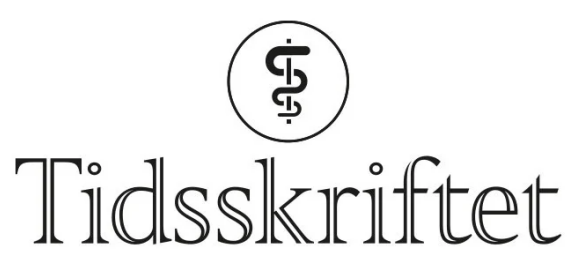

DEN NORSKE LEGEFORENING

\title{
Slegge og pinsett
}

DEBATT

\section{MARIT HERMANSEN}

marit.hermansen@legeforeningen.no

Marit Hermansen er president i Legeforeningen.

Forfatteren har fylt ut ICMJE-skjemaet og oppgir ingen interessekonflikter.

Vi er helt avhengige av engasjerte leger som sier ifra hvor skoen trykker. Jeg forstår utålmodigheten som Bjørg Bakke setter ord på i innlegget «Når spydspissen blir liggjande i skuffen» (1). Men kritikken mot Legeforeningen er skivebom.

Legeforeningen har gjennom pandemien kjempet for god faglig praksis og medlemmenes sikkerhet, rettigheter og rammevilkår. Det skjer både bak lukkede dører og for åpen mikrofon. Fra det øyeblikket koronaviruset traff Norge, har vi påvirket der beslutningene tas til medlemmenes, pasientenes og resten av helsetjenestens beste.

Medlemmenes sikkerhet og arbeidsmiljø er vår førsteprioritet. I starten av pandemien var mangelen på smittevernutstyr prekær. Vi presset på for å få tilgang til nødvendig utstyr for hele helsetjenesten og for mer åpenhet om fakta $(\underline{2}, 3)$. Vi kunne ikke akseptere at helsepersonell skulle ha mangelfull beskyttelse. Derfor satte vi foten ned og fikk endret retningslinjene.

\section{«Fra det øyeblikket koronaviruset traff Norge, har vi påvirket der \\ beslutningene tas til medlemmenes, pasientenes og resten av \\ helsetjenestens beste»}

Legeforeningen sørger for at medlemmenes erfaringer og syn på håndteringen av pandemien settes på dagsordenen, sist ut med vår underveisrapport om covid-19 (4). Mangel på intensivkapasitet har vært et sentralt tema. Legeforeningen har jobbet både over og under radaren for at helsepersonell skal prioriteres i vaksinekøen. Vi har fått gjennomslag i flere omganger. I siste runde rett før påske var vår innsats direkte utslagsgivende for regjeringens beslutning om å gi 34 ooo vaksiner til helsepersonell (5). Helseminister Bent Høie understreket selv Legeforeningens rolle og betydning for avgjørelsen. Vi nærmer oss nå målet som EU har satt, nemlig 8o \% vaksinedekning av helsepersonell.

\section{Mange gjennomslag}


De tillitsvalgte har med solid juridisk bistand forhandlet lokale og sentrale koronaavtaler og fått igjennom viktige koronatakster og karantenekompensasjon. Vi har bistått med rådgiving om avtaler, permisjonsregler og kompensasjonsordninger. Vi har også fått godkjent covid-19 som yrkessykdom. I dialog med Helsedirektoratet har vi fătt på plass nødvendige tilpasninger i kurs og spesialistregelverk. Hver eneste dag jobber Legeforeningens over 3 ooo tillitsvalgte for medlemmenes rammebetingelser og fagutøvelse. Deres innsats er uvurderlig.

Handlingsplanen for fastlegeordningen var tvingende nødvendig. Legeforeningen har fått gjennomslag for det meste av sin politikk. Men jobben er langt ifra ferdig. Midlene i handlingsplanen må komme raskere enn det som er planlagt. Og skal tiltakene gi ønsket effekt, må det bevilges enda mer (므).

I konflikten med Spekter i 2016 vant vi til slutt frem med vårt krav om kollektivt vern og rullerende arbeidsplaner for sykehuslegene (.7.). I fjor høst raslet enkelte organisasjoner med sablene og truet med streik, men Legeforeningen satte faktisk makt bak ordene. Vi gjennomførte en helt nødvendig streik for å få ned arbeidsbelastningen i legevakt (ㅁ). Bakke var selv en tydelig talsperson, godt hjulpet av Legeforeningen. Og streiken gjennomførte vi midt under en pandemi. Likevel klarte vi å vinne opinionen, samtidig som vi ivaretok et krevende samfunnsansvar. Rikslønnsnemnda i juni er neste steg.

\section{«Det er en kortslutning å tro at gjennomslagene øker proporsjonalt med} graden av utestemme»

Alt dette er påvirkningsarbeid som gir konkrete resultater. Noen gjennomslag kan vi miste av syne når vi står i en langvarig helsekrise, men det gjør dem ikke mindre viktige. Eksemplene viser med all tydelighet at Legeforeningen er et viktig og effektivt bindeledd mellom beslutningstakerne og helsetjenesten. Det er vårt mandat - og et ansvar vi tar på største alvor. Da er det underlig å lese påstander om feilslått strategi og passivitet.

Samtidig tar Bakke opp noe viktig. Ønsket om å oppnå mer forsterkes i den ekstraordinære situasjonen vi står i. Men det er en kortslutning å tro at gjennomslagene øker proporsjonalt med graden av utestemme. Politisk påvirkningsarbeid og strategisk kommunikasjon er både sammensatt og tidkrevende. Legeforeningen setter foten ned når det er nødvendig. $\AA$ påstå at vi ikke gjør det, er misvisende.

Legeforeningen er den interesseorganisasjonen som troner høyest på den siste kåringen av hvem som er mektigst i Helse-Norge (9.). Omverdenens vurdering av Legeforeningen er ikke tilfeldig. Et sterkt omdømme kommer ikke av seg selv. Plasseringen er et resultat av målrettet laginnsats over tid, der vi bruker både slegge og pinsett. Legeforeningen er, og skal fortsatt være, spydspissen for utviklingen av norsk helsetjeneste - og ikke minst for medlemmenes interesser.

\section{LITTERATUR \\ 1. Bakke B. Når spydspissen blir liggjande i skuffen. Tidsskr Nor Legeforen 2021; 141. doi: 10.4045/tidsskr.21.0212. [CrossRef] \\ 2. Den norske legeforening. Myndighetskontakt under covid-19-pandemien. https://www.legeforeningen.no/politikk-og-samfunn/informasjon-om- koronaviruset/Myndighetskontakt-under-covid-19-pandemien Lest 13.4.2021.}

3. Næss OHB, Husø A, Zondag MHW. Helsedirektoratet beklager begrunnelsen for å holde tallene om smittevernutstyr hemmelig. NRK 1.4.2020. https://www.nrk.no/norge/helsedirektoratet-beklagerbegrunnelsen-for-a-holde-tallene-om-smittevernutstyr-hemmelig-1.14969051 Lest 13.4.2021. 
4. Sæter AS. Legeforeningen:- Dårlig forberedt på den varslede krisen. VG 6.4.2021.

https://www.vg.no/nyheter/innenriks/i/6zQ]XW/legeforeningen-daarlig-forberedt-paa-den-varsledekrisen?fbclid=IwAR1QdsGAC9V3KgkSKolivjw4OmreoKakYygtJJChOIygRSLLtIUOx-bESSs Lest 13.4.2021.

5. Holmes MSC, Sæter AS, Hagfors CS et al. Tillitsvalgte slo alarm om situasjonen på sykehusene: Nå får de ekstra vaksiner. VG 21.3.2021. https://www.vg.no/nyheter/innenriks/i/dlMwlj/tillitsvalgte-sloalarm-om-situasjonen-paa-sykehusene-naa-faar-de-ekstra-vaksiner? fbclid=IwAR27poFRKz1C26mwX3ySrePDctMCOleHvyiL4qOW_bokN_NgrHio6LdU4Dg Lest 13.4.2021.

6. Dommerud T. Slik skal fastlegekrisen løses. Aftenposten 11.5.2020.

https://www.aftenposten.no/norge/i/zG2zJO/slik-skal-fastlegekrisen-loeses Lest 13.4.2021.

7. Moe M. Da Spekter ble slått knockout. Dagens Medisin 6.11.2017.

https://www.dagensmedisin.no/artikler/2017/11/o6/da-spekter-ble-slatt-knockout/ Lest 13.4.2021.

8. Bakken BV. Legestreiken i gang-varsler rask opptrapping. VG 26.10.2020.

https://www.vg.no/nyheter/innenriks/i/pAAAW1/legestreiken-i-gang-varsler-rask-opptrapping Lest 13.4.2021.

9. Dette er Helse-Norges 100 mektigste. Dagens Medisin 2.12.2020.

https://www.dagensmedisin.no/artikler/2020/12/o2/her-er-helse-norges-100-mektigste-for-2020/ Lest 13.4.2021.

Publisert:14. april 2021. Tidsskr Nor Legeforen. DOI: 10.4045/tidsskr.21.0293

Mottatt 8.4.2021, første revisjon innsendt 13.4.2021, godkjent 13.4.2021.

(C) Tidsskrift for Den norske legeforening 2023. Lastet ned fra tidsskriftet.no 26. april 2023. 